\title{
New record of a Middle Devonian brachiopod fauna from the Northern Arabian Plate, Zap Anticline, Çukurca-Hakkari, Southeastern Turkey
}

\author{
RÉMY GOURVENNEC \& IZZET HOŞGÖR
}

\begin{abstract}
Brachiopods recently collected from the Zap River Valley area (SE Turkey) allow to establish a Middle Devonian (upper Givetian) age for the upper middle part of the Yığınlı Formation which was until now considered as Famennian on the basis of its micropaleontological contents and of its relative position in the series. - Key words: brachiopods, Devonian, Yığınlı Fm., Turkey.
\end{abstract}

GouRVENNEC, R. \& HoȘGÖR, I. 2012. New record of a Middle Devonian brachiopod fauna from the Northern Arabian Plate, Zap Anticline, Çukurca-Hakkari, Southeastern Turkey. Bulletin of Geosciences 87(2), 347-358 (4 figures). Czech Geological Survey, Prague. ISSN 1214-1119. Manuscript received October 6, 2011; accepted in revised form January 27, 2012; published online March 16, 2012; issued March 30, 2012.

Rémy Gourvennec (corresponding author), CNRS UMR 6538 “Domaines Océaniques”, IUEM, Université de Bretagne Occidentale, Avenue Le Gorgeu, CS 93837, F-29238 Brest, France; remy.gourvennec@univ-brest.fr・Izzet Hoşgör, TransAtlantic Petroleum Ltd. - Viking Int.Ltd., TR 06680,Ankara,Turkey; izzet.hosgor@viking-intl.com

\section{Geological and stratigraphic setting}

The study area is located in southeastern Anatolia, along the northern margin of the Arabian plate of Gondwana (locality situated on the Northern limb of the Çukurca anticline, in Zap River Valley, Southeastern Turkey, GPS $37^{\circ} 17^{\prime} \mathrm{N}, 43^{\circ} 30^{\prime} \mathrm{E}$, Y1ğınlı Formation, approximate elevation $1280 \mathrm{~m}$ ). A previous work on this area was conducted during the field-mapping projects of the Turkish Petroleum Company (Perinçek 1980). In southeastern Turkey, Devonian rocks crop out in the Hakkari Province, between the towns of Hakkari and Çukurca which are situated close to the Iran and Iraq borders and now accessible (Yalçın \& Yilmaz 2010; Fig. 1). In the Hakkari area, the dominant Devonian-Lower Carboniferous lithology consists in brakish to marine, grey-black shale and shallow marine limestone (Bozdoğan \& Ertuğ 1997, Y1lmaz \& Duran 1997). The outcrops are still poorly known from a palaeontological point of view due to the difficulty to obtain access to this region in the past (Hoșgör et al. 2011, Webster \& Hoșgör, submitted).

Between Hakkari and Çukurca the Zap River incised a deep valley exposing two inliers of Cambrian and Ordovician deposits, mostly clastic, that form part of the Arabian Platform (Ghienne et al. 2010). Dean et al. (1981) demonstrated that shales and sandstones of Late Cambrian and Early Ordovician age representing the Seydișehir Formation described from the western
Taurus Mts, are widespread in the eastern Taurus, southeastern Turkey, and neighboring parts of Iraq. Disconformably overlying strata, mainly shales and siltstones, were named the Sort Tepe Formation and shown to be of Ashgillian age (Late Ordovician) (Dean \& Zhou 1988, Ghienne et al. 2010). In the Zap Valley the thick Seydișehir Formation is unconformably overlain by a Lower and Upper Paleozoic succession comprising four formations, that are in ascending order: the Upper Ordovician Șort Tepe Formation, the Devonian Yı̆̆ınlı Formation, the Upper Devonian-Lower Carboniferous Köprülü Formation and the Upper Permian Gomaniibrik Formation (Harbol limestones) (Köylüoğlu \& Altıner 1989, Bozdoğan \& Ertuğ 1997, Yılmaz \& Duran 1997, Higgs et al. 2002, Hoșgör et al. 2011; Fig. 2).

The Yığınlı Formation, named by Açıkbaș (1978), consists of pink, dark red-coloured, cross-bedded, quartzitic sandstones, which occasionally alternate with yellowish green, grey mudstones and shales. Its thickness in the Hakkari-Çukurca area is between 200-295 m (Perinçek et al. 1991, Yalçın \& Yılmaz 2010). Tunbridge (1988) in a sedimentological analysis, interpreted the Yığınlı Formation as a Famennian-age regressive-transgressive fluvio-deltaic clastic wedge and recognized five members within it. In ascending order the members include: dolomite and red shales, sandstones and grey shales, red sandstones and siltstones, sandstones and gray shales, and carbonates and grey shales. 

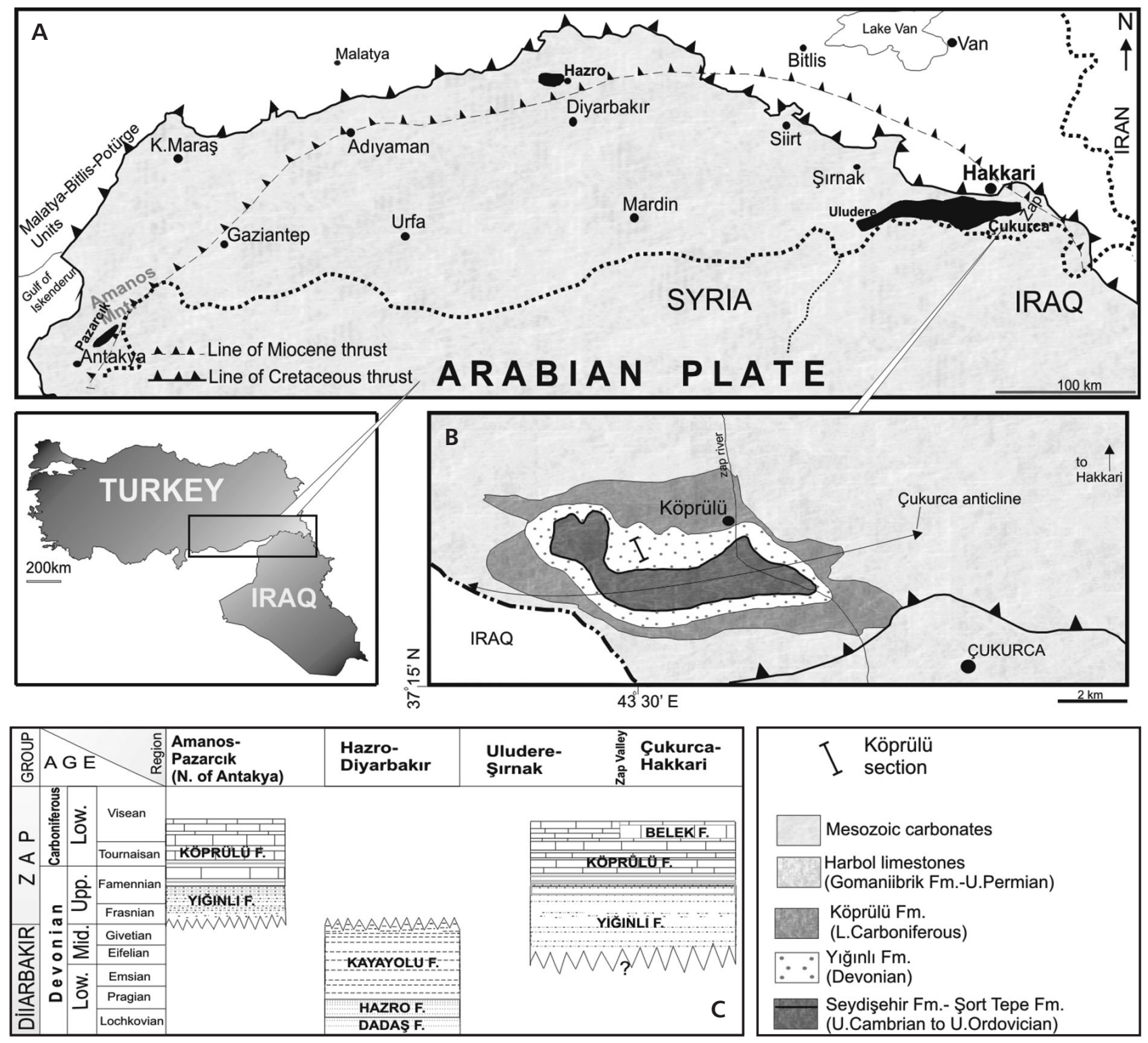

Figure 1. A - sketch map of Turkey showing location of the studied area on the North Arabian Plate. $\bullet B-$ geological map of the Zap Valley showing the position of the studied section. $\bullet \mathrm{C}$-generalized stratigraphic sections of the Devonian to Carboniferous rocks in southeastern Turkey (after Janvier $e t$ al. 1984, Hoșgör et al. 2011, Y1lmaz \& Duran 1997, Webster \& Hoșgör, submitted).

The fossil remains were discovered during field works undertaken by one of us (I.H.) in May 2010. The fossil material found in the Yı̆̆ınlı Formation is scarce. Studied brachiopods come from shell concentrations of various thicknesses, some of which are clay-silt horizons. Most fossils, including the brachiopods, are well preserved in the middle part of the Köprülü section (Fig. 2). Echinoderms of similar age have been recently reported from the Șort Dere section (Webster \& Hoşgör, submitted), located southeastern of the Köprülü section. So far, Devonian sequences were characterized by miospore taxa indicating a Famennian age and fish remains suggesting a Strunian age for the upper part of the Yiğınlı Formation (Higgs et al. 2002,
Janvier et al. 1984) and the only mention of the presence of Middle and Upper Devonian brachiopods in SE Turkey concerned the Kayayolu Fm., in the Hazro area, about $200 \mathrm{~km}$ northwest of the zone studied here (Tolun 1949, Lebküchner 1976).

\section{Systematic palaeontology}

Although the material described below is generally well preserved (complete shells), each taxon, as mentioned above, is represented by few specimens, so that internal structures were not investigated. Such an examination would have led 
Figure 2. Stratigraphic column of the studied units with detailed succession in the Köprülü section (after Janvier et al. 1984, Ghienne et al. 2010).

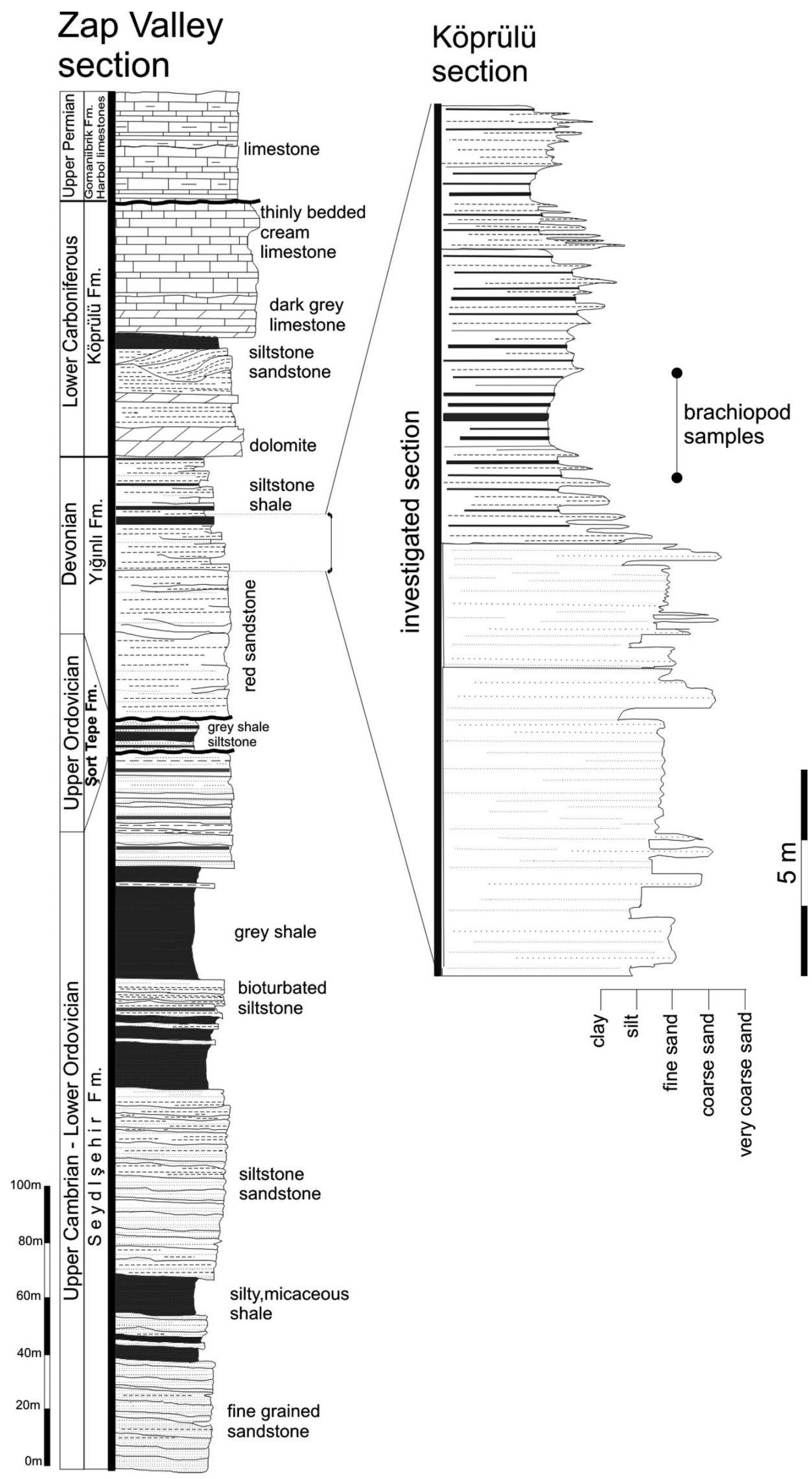


to the destruction of the specimens at hand. Further sampling in the area should allow more precise assignments and bring new light on Devonian faunas of Southeastern Turkey.

The material is housed in the Laboratoire de Paléontologie de Brest (LPB), Université de Bretagne Occidentale (France).

Order Productida Sarytcheva \& Sokolskaya, 1959

Suborder Chonetidina Muir-Wood, 1955

Superfamily Chonetoidea Bronn, 1862

Family Chonetidae Bronn, 1862

Subfamily Dagnachonetinae Racheboeuf, 1981

\section{Genus Dagnachonetes Afanas'eva, 1978}

\section{Dagnachonetes? sp.}

Figure $3 \mathrm{~A}-\mathrm{D}$

Material. - 2 ventral valves from level B6. No. LPB 19396.

Description. - The shell is small, slightly wider than long (length $\approx 10 \mathrm{~mm}$, width $\approx 12 \mathrm{~mm}$ ), convex (height $\approx 5 \mathrm{~mm}$ ) with a subtrapezoidal transverse section. The hinge is shorter than maximum width that is located approximately at mid-length. Numerous, very fine costellae covering the entire shell surface (about 80-90 costellae near the commissure), all identical in size and strength (no differentiated median costellae). New costellae appear either by intercalation or dichotomy. Very fine concentric fila can be seen locally on the shell, superposed to the radial ornament.

Interior unknown.

Remarks. - Due to the lack of dorsal valve and the impossibility to observe interior features, a generic assignment is very uneasy. Nevertheless, the micro-ornament of the shell and its overall shape is very reminiscent of Dagnachonetes, a genus known in the Middle Devonian (Eifelian-Givetian) of Europe, Russia and China.

Order Atrypida Rzhonsnitskaia, 1960

Suborder Atrypidina Moore, 1952

Superfamily Atrypoidea Gill, 1871

Family Atrypidae Gill, 1871

Subfamily Spinatrypinae Copper, 1978

\section{Genus Isospinatrypa Struve, 1966}

\section{Isospinatrypa aspera Schlotheim, 1813}

Figure 3E-I

Material. - 2 complete specimens from level B5. No. LPB 19395.

Description. - The shell is small (length $\approx 18 \mathrm{~mm}$, width $\approx$ $18.5 \mathrm{~mm}$ ), shield shaped to elongate, dorsibiconvex $(\mathrm{Hd} / \mathrm{Hv} \approx 1.5)$, with a transapical foramen and a relatively short hinge, the maximum width being located at midlength. Beak poorly developed. Delthyrium not visible. The anterior commissure is weakly plicate. Costae strong, rounded, about 15 on the entire shell dichotomizing near the commissure (3-4 costae per $5 \mathrm{~mm}$ there). Median costa slightly stronger and higher than lateral ones, dividing in early growth stage, each branch dividing again near the commissure. Growth lamellae relatively regularly spaced, bearing very fine concentric fila, and anteriorly developed in frills and hollow spines present on both valves.

Interior unknown.

Remarks. - The presence of well-developed frills and spines pleads in favor of an assignment to Spinatrypinae. The small size, general shape and slightly elevated median ribs are consistent with an assignment to Isospinatrypa, although interior remains unknown. The genus is known from the ?Lochkovian to the lower Givetian, worldwide. The general aspect of the shell, particularly the strong costae and the ornament is consistent with an assignment to the species I. aspera that is present sensu lato in upper Eifelian to Givetian deposits worldwide.

\section{Subfamily Variatrypinae Copper, 1978}

\section{Genus Variatrypa Copper, 1966}

\section{Variatrypa sp.}

Figure 3P-T

Material. - 1 complete specimen from level B7. No. LPB 19397d.

Figure 3. All specimens from Köprülü section, Yı̆̆ınlı Formation, SE Turkey. Scale bar $=1 \mathrm{~cm}$, unless otherwise indicated. • A-D - Dagnachonetes? sp. Ventral, posterior and lateral views of a ventral valve; D - detail of the ornament (scale bar = $1 \mathrm{~mm}$ ). LPB $19396 \mathrm{a}$. $\bullet$ E-I - Isospinatrypa aspera Schlotheim, 1813. Ventral, dorsal, anterior, posterior and lateral views of a complete specimen. LPB 19395a. • J-O - Desquamatia? sp. Ventral, anterior, posterior, lateral and dorsal views of a complete specimen; O - detail of the concentric ornament (scale bar $=5 \mathrm{~mm}$ ). LPB 19397a. $\bullet$ P-T - Variatrypa sp. Lateral, posterior, anterior, ventral and dorsal views of a complete specimen. LPB 19397d. $\bullet$ U-Y - Athyris concentrica (von Buch, 1834). Dorsal, ventral, lateral, anterior and posterior views of a complete specimen. LPB 19393a. 


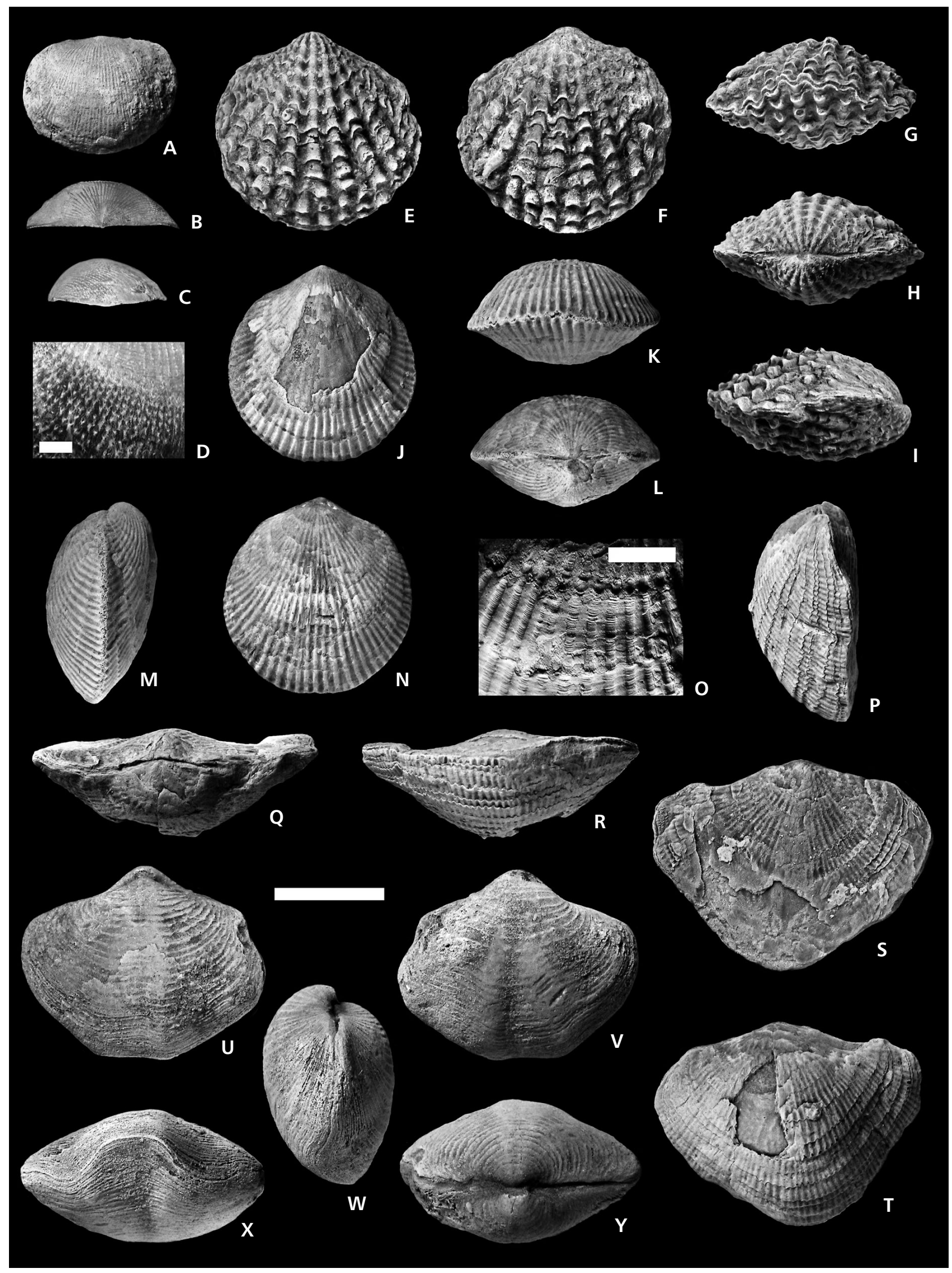


Description. - Shell of medium size, shield shaped to subtriangular, transverse (length $=18.5 \mathrm{~mm}$, width $=24 \mathrm{~mm}$ ), strongly dorsibiconvex with a long straight hinge. Maximum width slightly anterior to hinge. The dorsal valve is strongly convex, the ventral one almost plane $(\mathrm{Hd} / \mathrm{Hv}=5)$. The anterior commissure is rectimarginate. Numerous radial, very fine costae (about 80 costae on the commissure). The growth lamellae are weak, irregularly spaced and do not interrupt radial ornament, excepted near the anterior commissure where they develop short frills. They apparently bear traces of concentric fila but the shell surface is poorly preserved and this could be an artifact. The foramen is not exposed, hidden by the dorsal beak. Both ventral and dorsal areas are poorly developed.

Interior unknown.

Remarks. - The general shape of the shell, very long hinge, fine costae and the possible presence of concentric fila are consistent with an assignment to Variatrypa, despite the fact that the commissure is rectimarginate and interior features unknown. Variatrypa is cosmopolitan, present from the Emsian to the ?Frasnian. No known species presents a combination of characters similar to that observed in our material (subtriangular outline, almost flat ventral valve, etc.).

\section{Genus Desquamatia Alekseeva, 1960}

\section{Desquamatia? sp.}

Figure 3J-O

Material. - 3 complete valves from level B7. No. LPB 19397a-c.

Description. - Shell small, subcircular to slightly elongate (length $=17 \mathrm{~mm}$, width $=16 \mathrm{~mm}$ ), equivalve to slightly dorsibiconvex $(\mathrm{Hd} / \mathrm{Hv} \approx 1)$ with a short hinge. Both valves are poorly elevated. Anterior commissure rectimarginate. Ventral and dorsal areas low. Foramen transapical. Numerous, very fine costae appearing by dichotomy (about $50-60$ costae in the vicinity of the commissure). Growth lamellae poorly expressed, long and regularly spaced, with very fine concentric fila (Fig. 3O). Frills apparently lacking (but surface of shells very poorly preserved).

Interior unknown.

Remarks. - This species is assigned with doubt to Desquamatia: the outline, low convexity and fine ornament are consistent with such an assignment. Nonetheless, the presence of fila is not reported in Desquamatia that in addition generally possess a plicate commissure. The genus is known from the Pragian to the Frasnian all around the world.
Order Athyridida Boucot, Johnson \& Staton, 1964

Suborder Athyrididina Boucot, Johnson \& Staton, 1964

Superfamily Athyridoidea Davidson, 1881

Family Athyrididae Davidson, 1881

\section{Genus Athyris M'Coy, 1844}

\section{Athyris concentrica (von Buch, 1834) Figure 3U-Y}

Material. - 2 complete specimens, one of them strongly crushed, from level B3. No. LPB 19393.

Description. - Shell small to medium, equally biconvex, transverse (length $=17.5 \mathrm{~mm}$; width $=22 \mathrm{~mm}$ ) with widely rounded cardinal extremities, the maximum width being located at mid-length. Sulcus and fold, relatively wide (almost $1 / 2$ width), trapezoidal in transverse section, poorly expressed except near the anterior commissure that is uniplicate to slightly parasulcate. Ventral beak well developed, curved and pierced by an apical foramen. Ventral area short, with well marked growth lines parallel to hinge. Dorsal beak small, hidden by its ventral counterpart. The shell is smooth. Growth lamellae regularly spaced, more concentrated in the vicinity of the commissure where they develop in wide frills.

On the juvenile specimen, the dorsal valve is clearly higher than the ventral one but this specimen is strongly crushed. It possesses very long frills (about $3 \mathrm{~mm}$, the shell being $11 \mathrm{~mm}$ long).

Remarks. - The characteristics of this material are consistent with A. concentrica (sensu lato), a species widely distributed from the Middle Devonian to the Lower Carboniferous of the world. Nevertheless it should be noted that this species has never been firmly established. According to Alvarez et al. (1996) who revised the type species, the latter should be restricted to the material described by von Buch (1834), from the middle and upper Eifelian (Ahrdorf and Junkerberg formations, Eifel), but the name "concentrica" has been widely used to describe similar forms that are present up to the Carboniferous. It is to this informal group that we refer here.

Superfamily Meristelloidea Waagen, 1883

Family Meristidae Hall \& Clarke, 1895

\section{Genus Dicamara Hall \& Clarke, 1893}

Dicamara sp. cf. D. prunulum (Schnur, 1854)

Figure 4A-E

Material. - 2 complete shells from level B1. No. LPB 19391. 
Description. - Shell small to medium, subquadrate to elongate (length respectively $=21 \mathrm{~mm}$ and $18 \mathrm{~mm}$, width $=$ $19 \mathrm{~mm}$ and $14 \mathrm{~mm}$ ), with a strongly convex ventral valve and lower dorsal valve $(\mathrm{Hd} / \mathrm{Hv}$ respectively $=0.33$ and 0.57 ). Hinge astrophic. Maximum width located in the anterior third of the shell. Beaks robust on both valves strongly curved posteriorly on the ventral valve, hiding the dorsal one. Apical foramen present. Sulcus and fold lacking except in the immediate vicinity of the anterior commissure where they are only poorly expressed; the fold is slightly dorsally recurved at the commissure (Fig. 4C). Anterior commissure uniplicate with a wide subtrapezoidal tongue (sulcus width/width respectively 0.53 and 0.22 ). The shell is smooth. A few growth lamellae are visible, narrow posteriorly becoming gradually wider anteriorly.

Interior not observed. By transparency on one of the shells we can guess the presence of a thin, long dorsal median septum (about $1 / 3$ of L) and two straight, divergent, rather short dental plates (about $1 / 4$ of $\mathrm{L}$ ).

Remarks. - This form is assigned to Dicamara after its external aspect and the presence of a long dorsal septum and short dental plates. It is also reminiscent of Camarium that often present a recurved fold in the vicinity of the commissure, or to a lesser extent to Meristella. Only a detailed study of the interior could help in this matter. Our material is externally very close to the species $D$. prunulum, at least its elongate variants (the nominal species shows a wide range of variations in its outline), sharing with the latter a strong convexity, elongate outline, the lack of sulcus/fold and a long septum. The genus Dicamara is widely distributed in the lower-middle Devonian; the species D. prunulum is restricted to the middle-upper Eifelian (Ahrdorf to Freilingen Schichten, Eifel), hence also the presence of a "cf." here.

Superfamily Retzioidea Waagen, 1883

Family Neoretziidae Dagys, 1972

Subfamily Plectospirinae Alvarez, Rong \& Boucot, 1998

\section{Genus Plectospira Cooper, 1942}

\section{Plectospira ferita (von Buch, 1835)}

Figure 4F-M

Material. - 2 complete shells from level B4. No. LPB 19394.

Description. - Minute shells with subquadrate to slightly elongate outline, flat, equibiconvex (length respectively 9 and $7.5 \mathrm{~mm}$; width resp. 10 and $9 \mathrm{~mm}$; height resp. 4 and $4.5 \mathrm{~mm}$ ). Hinge short. Maximum width approximately at mid-length. Ventral beak robust strongly curved, acute, with obscure apical foramen. Ventral area low. Fold flattened at top, poorly expressed in juvenile stage, shallower than adjacent costae, rapidly increasing in height and width towards anterior, reaching almost $1 / 2$ of width at anterior margin; it bears a shallow median groove on its distal extremity. Sulcus flat bottomed, slightly elevated above flanks, lower than adjacent costae in juvenile stage, bearing a median costa anteriorly. Costae strong, few (3 on each side), subangular in section, strongly projecting externally at the commissure. Microornament consisting of small tubercles giving to the shell surface a punctuate appearance (Fig. 4K).

Interior unknown.

Remarks. - The features observed in this form undoubtedly allow an assignment to the genus Plectospira. The shell outline, its size, the strong costae projecting outwards anteriorly, and the nature of fold and sulcus indicate that this form belongs to the species Plectospira ferita. The genus is known from the Silurian (upper Ludlow) to the Lower Carboniferous; although some references can be found indicating its presence as soon as Pragian, the true representatives of the species P. ferita appear to be restricted to the Eifelian-Givetian period.

Order Spiriferida Waagen, 1883

Suborder Spiriferidina Waagen, 1883

Superfamily Cyrtospiriferoidea Termier \& Termier, 1949

Family Cyrtospiriferidae Termier \& Termier, 1949

\section{Genus Cyrtospirifer Nalivkin in Frederiks, 1924}

\section{Cyrtospirifer cf. C. verneuili (Murchison, 1840)}

Figure $4 \mathrm{~S}-\mathrm{Z}$

Material. - 2 complete shells from levels B8 and B9. No. LPB 19398-19399.

Description. - Shell medium to large (length respectively 23 and $25 \mathrm{~mm}$; width $47 \mathrm{~mm}$ in both shells), entirely costate, transverse, subquadrate in outline, with subangular cardinal extremities (lateral commissure almost normal to the hinge). The maximal width is located slightly before the hinge. The dorsal valve is equal to or slightly higher than the ventral one. Ventral area curved, apsacline, with a robust, strongly curved beak. Delthyrium triangular, wide, with fine, relatively high deltidial plates. Dorsal area low, anacline to apsacline. Fold rounded in section, costate (about 13 costae on fold), well delimited by grooves deeper than lateral ones. Sulcus shallow, widely rounded, costate, moderately wide (sulcus width/width at anterior margin $\approx$ 0.4). Costae rather fine, low, rounded, numerous (20-23 on each flank), separated by rounded grooves. Growth lamellae 
fine, irregularly spaced, more densely distributed close to the commissure, and bearing concentric minute fila.

Interior unknown. One shell with broken apex shows a strong apical thickening in the ventral valve and the presence of a delthyrial plate. The dental plates, located on the edge of the sulcus, are divergent and straight.

Remarks. - The features observed in this species are those of Cyrtospirifer verneuili although cardinal extremities are generally more acute (eventually mucronate) in the nominal species than in our specimens. The status of $C$. verneuili and allied species is unclear and needs a thorough revision that is not under the scope of this paper. Cyrtospirifer is present during the upper Devonian in many areas of the world but many species referred (or close) to $C$. verneuili have been mentioned as soon as the Middle Devonian, particularly in North Africa: Algeria (Bitam et al. 1996), Morocco (Schindler \& Wehrmann 2011), Mauritania (Racheboeuf et al. 2004), etc.

Order Spiriferinida Ivanova, 1972

Suborder Cyrtinidina Carter \& Johnson, 1994

Superfamily Cyrtinoidea Frederiks, 1911

Family Cyrtinidae Frederiks, 1911

\section{Genus Cyrtina Davidson, 1859}

\section{Cyrtina intermedia Oehlert, 1887 \\ Figure 4N-R}

Material. - 1 complete exfoliated shell from level B2. No. LPB 19392.

Description. - Shell punctate, small (length $=9 \mathrm{~mm}$; width $=13.5 \mathrm{~mm}$ ), transverse with suquadrangular outline. Cardinal extremities widely rounded, hinge shorter than width that is located around mid-length. Ventral valve pyramidal, dorsal valve weakly elevated. Fold low, flattened at top, wide, well delimited by grooves slightly deeper than adjacent ones. Sulcus shallow, rounded in section, wide (almost $1 / 2$ shell width at anterior edge) with bounding costae stronger than lateral ones. Lateral costae few ( 5 on each flank), external ones much attenuated, low, rounded. Growth lamellae irregularly spaced, poorly expressed (on an eroded shell surface). Ventral area high, triangular, asymmetric, topped by a poorly developed beak. Delthyrium closed at its base, open on the upper third, under the beak. Dorsal area very low, almost not expressed.

Interior unknown.

Remarks. - This form is assigned to C. intermedia after its general shape and number of costae. C. multicostata is very close to the present form but possesses more lateral costae. The species is known in Lower and Middle Devonian.

\section{Discussion}

Previously published data concerning this area deal with vertebrate faunas sampled in the top of the Yığınlı Formation and the lower part of the Köprülü Formation (Janvier et al. 1984). The top of the Yığınlı Formation was dated as Uppermost Devonian (Famennian), an age that was confirmed by the study of microflora (Higgs et al. 2002). In the latter study, two samples (respectively Zap 1 and Zap 2) were collected below the level yielding vertebrate remains and are possibly contemporaneous of our brachiopod fauna; they were dated as Famennian, with two identified palynomorph assemblages. Nevertheless, the lack of faunal control in the local sequences led the authors to correlate these assemblages with Western European ones, thereby introducing some uncertainty in the strength of the correlation and age estimation. The Verruciretusispora loboziakii assemblage was correlated with the Vallatisporites hystricosus-Apiculiretusispora verrucosa (VH) assemblage of Famennian age in Western Europe (Fa2c). The second one, namely Retispora lepidophyta assemblage, was correlated with the Retispora lepidophyta-Knoxisporites literatus (LL) and Retispora lepidophyta-Indotriradites explanatus (LE) assemblages of Strunian (latest Famennian) age also in Western Europe.

As far as these levels are effectively contemporary of the levels studied here (middle part of the Köprülü section) these results are not compatible with those concerning brachiopods. Although the assignments are made only at the generic level for a significant part of the material examined here, an estimation of the age of this assemblage can be reasonably stated and it is older than that indicated in the studies mentioned above. Actually the presence of

Figure 4. All specimens from Köprülü section, Yı̆̆ınlı Formation, SE Turkey. Top scale bar = $1 \mathrm{~cm}$, for figures A-R, except figure K (scale bar = $0.5 \mathrm{~mm}$ ); bottom scale bar $=1 \mathrm{~cm}$, for figures S-Z. $\bullet$ A-E - Dicamara sp. cf. D. prunulum (Schnur, 1854). Dorsal, ventral, lateral, anterior and posterior views of a complete specimen. LPB 19391a. $\bullet$ F-M - Plectospira ferita (von Buch, 1835). F-J - dorsal, posterior, ventral, anterior and lateral and views of a small complete specimen; K - detail of the ornament of the same (scale bar $=0.5 \mathrm{~mm}$ ), LPB 19394a; L, M - ventral and lateral views of another specimen, LPB 19394b. $\bullet \mathrm{N}-\mathrm{R}-$ Cyrtina intermedia Oehlert, 1887. Posterior, lateral, anterior, ventral and dorsal views of a complete, slightly damaged (exfoliated) specimen. LPB 19392. - S-Z - Cyrtospirifer cf. C. verneuili (Murchison, 1840). S-W - dorsal, posterior, ventral, lateral and anterior views of specimen LPB 19398; X-Z - anterior, lateral and posterior views of specimen LPB 19399. 


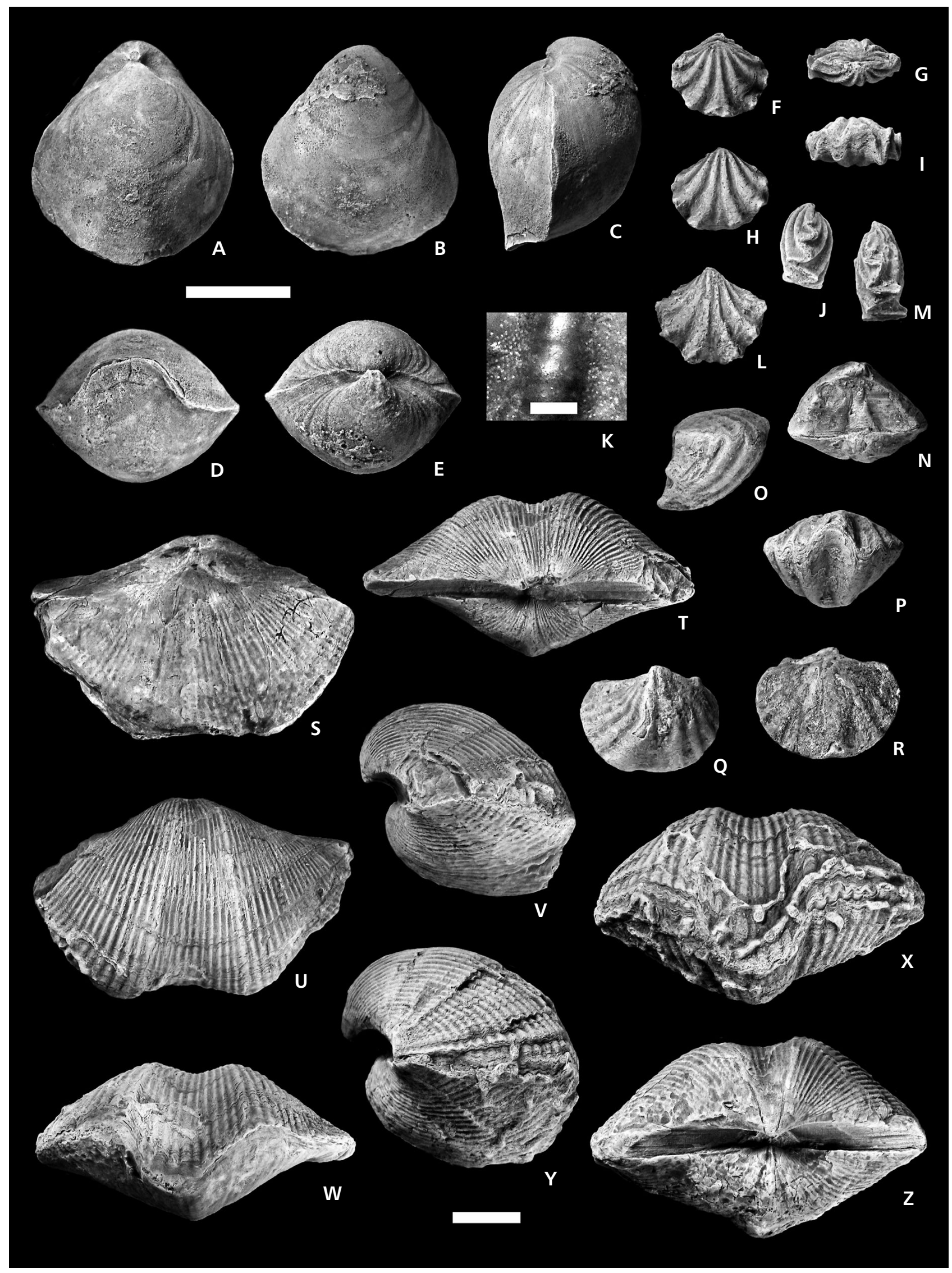


Atrypids precludes an age younger than the lower Frasnian. Other elements such as Dagnachonetes, Dicamara, Plectospira ferita and Cyrtina intermedia do not cross the Middle-Upper Devonian limit. Isospinatrypa aspera is present from the upper Eifelian to the Givetian. On the other hand, Cyrtospirifer is rather known to be a representative of upper Devonian faunas, but many occurrences of the species $C$. verneuili, or closely related forms described as "C. verneuili", $C$. cf. verneuili or $C$. sp. e.g. verneuili, have been recorded in many areas as soon as Middle Devonian (Givetian). Such a combination of genera of middle and upper Devonian affinities suggests a Givetian and most likely an upper Givetian age for this assemblage. This dating could probably be refined after sampling of complementary material that would allow the study of internal structures, but as mentioned above, brachiopod fauna is scarce in this formation. Anyway the age of this part of the Yığınlı Formation has thus to be modified in consequence. This is reinforced by a study of the echinoderms (Webster \& Hoșgör, submitted) that suggests a middle Devonian age for crinoids remains from the Unit 4 of the Yığınlı Formation. Unfortunately these specimens were not sampled in place and their precise stratigraphic location is in need of a closer examination, but their presence is a further element in favor of a revision of the age of the series in the direction that we suggest herein. The exact position of the Köprülü section in the Yığınlı Formation remains to be clarified in order to reinforce our results, but it is clear that the earliest levels of this formation had already begun to settle since the Middle Devonian.

The Paleozoic evolution of Southeast Turkey was influenced by three main variables: global eustatic sea-level changes, regional tectonics related to major orogenic events and the formation of Neotethys and local tectonics related to intracontinental rifting and other subsidence variations (Cater \& Tunbridge 1992). Paleogeographically the Late Ordovician to Early Carboniferous of northern Arabia suggests that North Africa and Arabia formed a broad stable continental shelf on the northern margin of the Gondwana supercontinent bordering the Paleo-Tethys Ocean. Studies of the Devonian-Early Carboniferous rocks in the north of Arabian plate show that they were deposited in either terrestrial or shallow marine environments (Beydoun 1991, Al-Juboury \& Al-Hadidy 2009, Najafzadeh et al. 2010, Hoşgör et al. 2011). Typical shallow-marine deposits are recorded in southern Turkey (Cater \& Tunbridge 1992), northern Syria (Best et al. 1993), northwest Iran (Najafzadeh et al. 2010) and northern Iraq (Wolfard 1981). The Devonian and Lower Carboniferous of the Arabian Plate is represented in Southeastern Anatolia (Fig. 1A, C) by sedimentary sequences observed from west to east in the Amanos Mountains, Hazro High and Hakkari area (Yalçın \& Y1lmaz 2010). The material described here is the first record of a Middle Devonian fauna in the Hakkari area.
From a paleontological point of view, the comparison with neighboring areas of Turkey, and more generally of the Middle East, is uneasy due to lack of data on brachiopods of this period. If faunas of Lower and Upper Devonian have been reported and/or described in several surrounding areas, the Middle Devonian period is much less documented. In SE Anatolia which belongs to the Arabian plate as mentioned above, a possible correlation should be considered between the base of Yığınlı Formation and the top of the Kayayolu Formation (Hazro area) which yielded some brachiopods (including Atrypa, Cyrtospirifer verneuili, Athyris concentrica, Cyrtina, etc.) (Tolun 1949, Lebküchner 1976) suggesting a broad Eifelian to Frasnian age (Fig. 1C). In other terranes constituting the rest of Turkey (Pontides and Taurides), considered as allochton units, no fauna comparable to that described herein has been so far discovered, but Middle Devonian was recognized in the Pontides (Manastır Member of the Y1lanlı Formation, Givetian) (Boncheva et al. 2009) and in Central and Eastern Taurides (Safak Tepe Formation, Eifelian-Givetian; Göncüoğlu et al. 2004, Sayar et al. 2009). No Givetian brachiopods fauna have been reported in neighboring areas belonging to the Arabian plate, respectively Syria, Jordan and Oman for which no deposit of the Middle Devonian has been recognized. In Iraq the Devonian is represented by the Pirispiki Formation that is devoid of fossils (Al-Juboury \& Hadidy 2009). In Saudi Arabia, the Jubah Formation corresponds pro parte (lower part of the formation) to the series studied here, but has not yielded brachiopods and was dated on the basis of its palynomorphs contents (Marshall et al. 2007).

In northern Iran we do not know brachiopod communities precisely attributed to the Givetian, nor in SE Iran where Middle Devonian deposits are seemingly lacking. Brachiopods identified in Central Iran (Zefreh section, Brice 2006) differ of our material and appear to be older (probably Eifelian). In Afghanistan some fauna have been attributed to the Givetian (Brice 1971) but they are dominated by spiriferids and rhynchonellids, the latter being curiously absent from the assemblage collected in Zap Anticline, and this prevents meaningful comparisons between these regions. The same applies for the Russian platform and the Timan area and westwards, Libya and Algeria.

At the generic level, the taxa from Zap Anticline are known in many other areas of the world, a situation that was expected in the context of increasing cosmopolitanism observed during the Givetian and later. Among the most interesting genera, one can point out Dagnachonetes that is known in Europe (Poland, France, Spain), Russia and China, Dicamara also reported in Europe (Poland, France, Spain, Germany, Moravia), North Africa (Algeria) and Asia (Salair, Kazakhstan, India, China) and Plectospira known in Europe (Poland, Germany, Czech Republic), 
Asia (Altai, Kuznetsk, Myanmar, Thailand, China) and Australia (New South Wales) during this period. The remaining genera are worldwide distributed. These data are consistent with the closure of the Rheic between Gondwana and Laurussia at this time and with a relatively narrow, incipient Palaeotethys.

\section{Acknowledgements}

Authors thank Denise Brice (Lille) and an anonymous reviewer for their useful comments that helped to improve the manuscript.

\section{References}

Açikваș, D. 1978. Geology and hydrocarbon potential of the Çukurca, Köprüliu, Yığınlı (Hakkari Province) Area. 52 pp. MSc thesis, Department of Geological Engineering, Istanbul University. [in Turkish]

Afanas'eva, G.A. 1978. Novyye khonetatsei iz devona Nakhichevanskoy ASSR [New Chonetacea from the Devonian of the Nakichevan ASSR]. Paleontologicheskii Zhurnal 1978(3), 64-71. [in Russian]

AlekseEvA, R.E. 1960. O novom podrode Atrypa (Desquamatia) subgen. nov. iz sem. Atrypidae Gill (Brakhiopody) [A new subgenus Atrypa (Desquamatia) subgen. nov. of the family Atrypidae Gill (brachiopods)]. Doklady Akademii Nauk SSSR 131(2), 421-424. [in Russian]

Al-Juboury, A.I. \& Al-Hadidy, A.H. 2009. Petrology and depositional evolution of the Paleozoic rocks of Iraq. Marine and Petroleum Geology 26(2), 208-231. DOI 10.1016/j.marpetgeo.2007.11.001

Altinli, E. 1954. The Geology of Southern Hakkari. Revue de la Faculté des Sciences de L'Université d'Istanbul 1, 33-65.

Alvarez, F., Brunton, C.H.C. \& Struve, W. 1996. On Athyris (Brachiopoda) and its type species "Terebratula" concentrica von Buch. Senckenbergiana lethaea 76(1/2), 65-105.

Best, J.A., Barazangi, M., Al SaAd, D., Sawaf, T. \& Gebran, A. 1993. Continental margin evolution of the Northern Arabia Platform in Syria. American Association of Petroleum Geologists, Bulletin 77, 173-293.

BeYdoun, Z.R. 1991. Arabian Plate hydrocarbon geology and potential: A plate tectonic approach. American Association of Petroleum Geologists 33, 1-77.

Bitam, L., Gourvennec, R. \& Robardet, M. 1996 (1997). Les formations paléozoïques anté-carbonifères du sous-bassin de Djebilet (flanc sud du Bassin de Tindouf, Nord-Ouest du Sahara algérien), 91-111. In BITAM, L. \& FABRE, J. (eds) Géodynamique du craton ouest africain central et oriental: héritage et évolution post-panafricains. Mémoires du Service Géologique d'Algérie 8.

Boncheva, I., GöncüoĞlu, M.C., Leslie, S.A., Lakova, I., Sachanski, V., SAydam, G., Gedik, I. \& Königshof, P. 2009. New conodont and palynological data from the Lower Palaeozoic in Northern Camdag, NW Anatolia, Turkey. Acta Geologica Polonica 59, 157-171.
BozdoĞAn, N. \& ERTuĞ, K. 1997. Geological evolution and paleogoegraphy of the southeast Anatolia in the Paleozoic, 39-49. In GÖNCÜOĞLU, M.C. \& DeRMAN, A.S. (eds) Early Paleozoic Evolution in NW Gondwana (Proceedings). Turkish Association of Petroleum Geologists Special Publication 3.

BRICE, D. 1971. Etude paléontologique et stratigraphique du Dévonien de l'Afghanistan. Notes et Mémoires sur le Moyen Orient 11, 1-364.

Brice, D. 2006. Devonian brachiopods from the Zefreh section (Central Iran). Annales de la Société géologique du Nord 13 (2e série), 141-155.

Buch, L. von 1834 (1835). Über Terebrateln, mit einem Versuch sie zu classificiren und zu beschreiben. Physikalische Abhandlungen Königliche Akademie für Wissenchaften aus den Jahre 1833, 1-124 (21-144).

Cater, J.M.L. \& Tunbridge, I.P. 1992. Palaeozoic tectonic history of SE Turkey. Journal of Petroleum Geology 15(1), 35-50. DOI 10.1111/j.1747-5457.1992.tb00864.x

Cooper, G.A. 1942. New genera of North American brachiopods. Washington Academy of Sciences, Journal 32(8), 228-235.

COPPER, P. 1966. The Atrypa zonata brachiopod group in the Eifel, Germany. Senckenbergiana lethaea 47(1), 1-55.

DAVIDSON, T. 1859 (in 1858-1863). A monograph of the British fossil Brachiopoda, Carboniferous, vol. 2, part 5. 280 pp. Palaeontographical Society Monograph, London.

Dean, W.T., Monod, O. \& PerinçeK, D. 1981. Correlation of Cambrian and Ordovician rocks in SE Turkey. Turkish Association of Petroleum Geologists 25, 269-291.

DeAn, W.T. \& Zhou, Z. 1988. Upper Ordovician trilobites from the Zap Valley, south-east Turkey. Palaeontology 31, 621-649.

Ghienne, J.F., Monod, O., Kozlu, H. \& Dean, W.T. 2010. Cambrian-Ordovician depositional sequences in the Middle East: A perspective from Turkey. Earth-Science Reviews 101, 101-146. DOI 10.1016/j.earscirev.2010.04.004

GöNCÜOĞLu, M.C., GöNCÜOĞLu, Y., Kozlu, H.W. \& Kozur, H. 2004. Paleozoic stratigraphy of the Geyik Daği Unit in the Eastern Taurides (Turkey): new age data and implications for Gondwanan evolution. Geologica Carpathica 55(6), 433-447.

Hall, J. \& Clarke, J.M. 1893. An introduction to the study of the genera of Palaeozoic Brachiopoda. Palaeontology of New York, vol. 8, Part 2. 317 pp. Charles van Benthuysen \& Sons, Albany.

Higgs, T.D., Finucance, D. \& Tunbridge, I.P. 2002. Late Devonian and early Carboniferous microfloras from the Hakkari Province of southeastern Turkey. Review of Palaeobotany and Palynology 118, 141-156.

DOI 10.1016/S0034-6667(01)00111-7

HoșGÖr, I., OKAn, Y. \& GÖNCÜOĞLU, M.C. 2011. Posidonia becheri Bronn, 1828 from the Tournaisian of SE Turkey: A palaeobiogeographic enigma. Comptes Rendus Palevol. DOI 10.1016/j.crpv.2011.09.003

Janvier, P., Lethiers, F., Monod, O. \& Balkaș, Ö. 1984. Discovery of a vertebrate fauna at the Devonian-Carboniferous boundary in SE Turkey (Hakkari Province). Journal of Petroleum Geology 7, 147-168. DOI 10.1111/j.1747-5457.1984.tb00172.x 
KöYlÜOĞLU, M. \& Altiner, D. 1989. Micropaléontologie (Foraminifères) et biostratigraphie du Permien supérieur de la région d'Hakkari (SE Turquie). Revue de Paléobiologie 8, 467-503.

LEBKÜCHNER, R. 1976. Beitrag zur Kenntniss des paleozoischen Kerns von Hazro Antiklinale in Südost Anatolien. Bulletin of Mineral Resource Exploration 86, 1-13.

M'Coy, F. 1844. A synopsis of the characters of the Carboniferous Limestone Fossils of Ireland. 207 pp. Printed at the University Press by M.H. Gill, Dublin. [Also printed by Williams \& Norgate, London.]

Marshall, J., Miller, M.A., Filatoff, J. \& Al-Shahab, K. 2007. Two new Middle Devonian megaspores from Saudi Arabia. Revue de Micropaléontologie 50, 73-79. DOI 10.1016/j.revmic.2007.01.006

Murchison, R.I. 1840. Sur les roches dévoniennes [type particulier de l'Old Red Sandstone des géologues anglais] qui se trouvent dans le Boulonnais. Bulletin de la Société géologique de France 11, 229-256.

NajafZAdeh, A., JafarZadeh, M. \& Moussavi-Harami, R. 2010. Provenance and tectonic setting of Upper Devonian sandstones from Ilanqareh Formation (NW Iran). Revista Mexicana de Ciencias Geológicas 27, 545-561.

NALIVKIN, D.V. in FrederiKs, G. 1924. Ussuriiskii verkhnii paleozoi. I. Brachiopoda [Upper Paleozoic of the Ussuriland, I: Brachiopoda]. Materialy po geologii i poleznym iskopaemym Dal'nego Vostoka 28, 1-53. [in Russian]

OeHLERT, D.P. 1887. Études sur quelques fossiles dévoniens de l'Ouest de la France. Bibliothèque de l'École des Hautes Études, Section des Sciences Naturelles 33(1), 1-80.

PerinçeK, D. 1980. Sedimentation on the Arabian shelf under the control of tectonic activity in Taurid belt. Proceedings of the $1^{\text {st }}$ Petroleum Congress, 77-93.

PerinçeK, D. 1990. Stratigraphy of the Hakkari Province, Southeast Turkey. TAPG Bulletin 2, 21-68.

Perinçek, D., Duran, O., Bozdogan, N. \& Çoruh, T. 1991. Stratigraphy and paleogeographical evolution of the autochthonous sedimentary rocks in Southeast Turkey, 274-305. In Turgut, S. (ed.) Tectonics and hydrocarbon potential of Anatolia and surrounding regions. Ozan Sungurlu Symposium, Proceedings of the Turkish Petroleum Corporation, Turkish Association of Petroleum Geologists. [in Turkish]

Racheboeuf, P.R., Gourvennec, R., Deynoux, M. \& Brice, D.
2004. The Devonian of the Hodh area (Islamic Republic of Mauritania): Paleontology, stratigraphy and paleobiogeographic implications. Journal of Paleontology 78(1), 98-110. DOI 10.1666/0022-3360(2004)078<0098:TDOTHA >2.0.CO;2

SAYAR, C., Yilmaz, I. \& BARGU, S. 2009. Stratigraphy and fossils of Middle, Upper Devonian and Carboniferous from Saimbeyli, Eastern Taurides, Turkey. Türkiye Jeoloji Kurultay 62, 664-665.

Schindler, E. \& Wehrmann, A. 2011. Genesis and internal architecture of the Middle to Upper Devonian Gwirat Al Hyssan reef-mound (Western Sahara). Palaeogeography, Palaeoclimatology, Palaeoecology 304(1-2), 184-193.

DOI 10.1016/j.palaeo.2010.10.017

SCHLOTHEIM, E.F. von 1813. Beiträge zur Naturgeschichte der Versteinerungen in geognostischer Hinsicht, 1-134. In LEONHARD, C.C. (ed.) Taschenbuch für die gesammte Mineralogie mit Hinsicht auf die neuesten Entdeckungen 7(1). Hermannschen Buchhandlung, Frankfurt am Main.

SCHNUR, J. 1854 (1853). Zusammenstellung und Beschreibung sämmtlicher im Übergangsgebirge der Eifel vorkommenden Brachiopoden. Palaeontographica 3, 169-254.

Struve, W. 1966. Einige Atrypinae aus dem Silurium und Devon. Senckenbergiana lethaea 47, 123-163.

Tolun, N. 1949. Geologic notes on the Silvan ve Hazru area. Bulletin of the Geological Society of Turkey 02(1), 65-89. [in Turkish]

TunBridge, I.P. 1988. The Upper Devonian clastic wedge in southeastern Turkey, 309-311. In McMillian, N.J., EMBrey, A.F. \& Glass, D.J. (eds) Devonian of the World. Canadian Society of Petroleum Geologists, Memoirs 14.

Webster, G.D. \& HoșGÖR, I. submitted. Paleozoic (Devonian, Mississippian and probable Permian) echinoderms from southeastern Turkey. Palaeoworld.

Wolfard, R. 1981. Lower Paleozoic of the Middle East, 6-130. In Holland, C.H. (ed.) Lower Paleozoic of the Middle East, Eastern and Southern Africa and Antarctica. Wiley, New York.

Yalçin, N. \& Yilmaz, I. 2010. Devonian in Turkey, a review. Geologica Carpathica 61(3), 235-253.

DOI 10.2478/v10096-010-0014-3

Yilmaz, E. \& Duran, O. 1997. Nomenclature of autochthonous and allochtonous units in Southeastern Anatolia - 'Lexicon'. Türkiye Petrolleri Anonim Ortaklı̆̆g, Araștırma Merkezi Grubu Bașkanlı̆̆ Eğitim Yayınları 31, 1-460. [in Turkish] 